\title{
Evaluation of Control Methods for Sosnowsky's Hogweed Heracleum sosnowskyi in Rezekne Municipality: the Results of a Survey of Experts
}

\author{
Anda ZVAIGZNE ${ }^{1}$, Inta KOTANE², Anna MEZAKA ${ }^{3}$
}

\author{
${ }^{1}$ Dr.oec., leading researcher and an associate professor, \\ Rezekne Academy of Technologies, Rezekne, Latvia, \\ e-mail: andazvaigzne@inbox.lv, phone: +371 26307669 \\ ${ }^{2} \mathrm{Mg}$.oec., researcher and lecturer, \\ Rezekne Academy of Technologies, Rezekne, Latvia, \\ e-mail: inta@ru.lv, phone: +37129415644 \\ ${ }^{3}$ Dr.biol., leading researcher and visiting assistant professor, \\ Rezekne Academy of Technologies, \\ e-mail: anna.mezaka@ru.lv, phone: +37126873683
}

\begin{abstract}
An increasing number of scientists as well as the public discuss the spread of invasive alien species that replace local species. One of such species is Sosnowsky's hogweed that creates problems to land owners and managers as well as local residents in Rezekne municipality.

The aim of the paper is to assess expert opinions on the application of control methods for Sosnowsky's hogweed in Rezekne municipality. To achieve the aim, the following specific research tasks were set: 1) to describe the situation with the spread of Sosnowsky's hogweed in Rezekne municipality; 2) to identify the most effective methods of control for Sosnowsky's hogweed and their application in Rezekne municipality by employing the expert method.

Research methods used: monographic, descriptive, analysis, synthesis, data grouping and a sociological method - an expert survey/interview. Kendall's $W$ was employed to analyse the extent of agreement among the experts.

The research results showed that in general the experts were quite unanimous ( $W=0.59)$ and regarded the combined method, chemical control (application of herbicides) and soil tillage as the most effective methods to control Sosnowsky's hogweed. Also, the experts supposed that land owners and managers in Rezekne municipality did not choose the most effective and efficient control methods for Sosnowsky's hogweed.

The paper has been elaborated with the financial support of Rezekne Academy of Technologies provided through a research grant.
\end{abstract}

Keywords: Sosnowsky's hogweed, land owners and managers, the most effective methods, expert opinion, Rezekne municipality.

JEL code: $Q 1, Q 5$

\section{Introduction}

The number of invasive alien species in the flora of Latvia increases from year to year. A lot of such species grow and spread very well in Latvia; as a result, the invasive alien species replace local species and occupy 
certain habitats. Aggressive alien species that eliminate local species are called invasive species (Bērziñš et al., 2007).

An increasing number of scientists as well as the public discuss the spread of invasive alien species that replace local species. According to research investigations, the spread of such species has to be limited and it is necessary to disseminate information on the ways of controlling them.

Invasive alien species are one of the most urgent problems to be addressed to maintain biodiversity in the world (Biologiskās daudzveidības..., 1996). Sosnowsky's hogweed (Heracleum sosnowskyi) has been included in Latvia's list of invasive alien species.

The entry of Sosnowsky's hogweed into Latvia dates back to the late 1940s when it was started to be grown as a prospective feed crop on experimental farms. Sosnowsky's hogweed started gradually invading vast territories in semi-natural habitats (Laivins, Gavrilova, 2003). Sosnowsky's hogweed is currently present in vast territories in monodominant stands in Latvia (Priede, 2008).

A strategy for controlling Sosnowsky's hogweed in Latvia has to be based on three key principles: the botany of the plant (its seeds get ripe and the plant dies), government policy (aimed at promoting the management of land and educating the public) and the availability of practical measures (control methods have to be ease to use and efficient) (Bīstamais iebrucējs..., 2013).

The research aim is to assess expert opinions on the application of methods of controlling Sosnowsky's hogweed in Rezekne municipality.

To achieve the aim, the following specific research tasks were set: 1) to describe the situation with the spread of Sosnowsky's hogweed in Rezekne municipality; 2) to identify the most effective methods of control for Sosnowsky's hogweed and their application in Rezekne municipality by employing the expert method.

Hypothesis: land owners and managers in Rezekne municipality choose the most effective or ineffective control methods for Sosnowsky's hogweed.

Research methods used: monographic, descriptive, analysis, synthesis, data grouping and a sociological method - an expert survey/interview. Kendall's W was employed to analyse the extent of agreement among the experts.

The present research is based on research papers, studies, surveys of experts and other information sources.

The research was elaborated with the financial assistance of Rezekne Academy of Technologies provided through a research grant for the "Investigation into the Information Society regarding the Control and Hazards of Sosnowsky's Hogweed in Rezekne Municipality". 


\section{Spread of Sosnowsky's hogweed in Rezekne municipality}

In the period 2007-2013, according to land surveys, Sosnowsky's hogweed grew in an area of 10640.99 ha in Latvia (Vilcāne, 2013).

According to the local government of Rezekne municipality, land surveyors identified Sosnowsky's hogweed in an area of 84.39 ha in 16 out of 25 rural territories of Rezekne municipality in 2012. The largest area with this plant, 57.38 ha or $66.42 \%$ of the total area of the municipality's area with the plant, was identified in Berzgale rural territory (Table 1) (Rēzeknes novada..., 2016).

In Rezekne municipality's specially protected natural territories as well as outside these territories Sosnowsky's hogweed negatively influences biodiversity as well as the visual values of its landscape, reducing the esthetical and biological quality of the landscape. The invasion of Sosnowsky's hogweed in Razna National Park, which is located in Rezekne municipality, is mainly observed in unmanaged and abandoned areas as well as in habitats with specially protected species (Tripāne, 2013).

Table 1

Spread of Sosnowsky's hogweed (ha, \%) in the rural territories of Rezekne municipality in 2012 (authors' construction based on the information provided by Rezekne municipality)

\begin{tabular}{|l|l|c|c|}
\hline No & Rural territory & Hectares & \% \\
\hline 1 & Berzgale & 57.38 & 66.42 \\
\hline 2 & Silmalas & 7.99 & 9.25 \\
\hline 3 & Nagli & 7.3 & 8.45 \\
\hline 4 & Makonkalns & 4.6 & 5.32 \\
\hline 5 & Cornaja & 3.14 & 3.63 \\
\hline 6 & Ozolmuiza & 3.12 & 3.61 \\
\hline 7 & Ozolaine & 0.9 & 1.04 \\
\hline 8 & Feimani & 0.55 & 0.64 \\
\hline 9 & Veremi & 0.5 & 0.58 \\
\hline 10 & Luznava & 0.31 & 0.36 \\
\hline 11 & Griskani & 0.27 & 0.31 \\
\hline 12 & Malta & 0.11 & 0.13 \\
\hline 13 & Nautreni & 0.1 & 0.12 \\
\hline 14 & Kaunata & 0.06 & 0.07 \\
\hline 15 & Lendzi & 0.05 & 0.06 \\
\hline 16 & Struzani & 0.014 & 0.02 \\
\hline & & 84.39 & 100 \\
\hline
\end{tabular}


The National Biodiversity Programme refers to Sosnowsky's hogweed as a very expansive species, as it can spread and grow in weedy areas and along roads as well as in natural meadows. According to available research studies on the control of Sosnowsky's hogweed, it is almost impossible to completely eliminate the plant (Biologiskās daudzveidības..., 2003).

As Sosnowsky's hogweed spreads, local species are endangered. Hogweed areas are mainly identified in grassland, including natural grassland, which is one of the habitats richest in species in Latvia. The invasion of Sosnowsky's hogweed reduces the quality of habitats and leads to the local elimination of species specific to the habitats, as well as decreases the number of areas with specially protected species (Tripāne, 2013).

It is possible to limit the spread of Sosnowsky's hogweed in Rezekne municipality only if engaging all land owners and managers; therefore, it is necessary to identify experts' opinions on the most appropriate and efficient control methods for Sosnowsky's hogweed in the municipality.

\section{Results of a survey and interviews of experts regarding control methods for Sosnowsky's hogweed and their application in Rezekne municipality}

The survey of experts aimed to identify their opinions on the effectiveness and application of control methods for Sosnowsky's hogweed as well as to assess public awareness of it in Rezekne municipality. The survey involved seven experts of relevant fields. The experts were selected based on their education level (Experts A and D had a master's degree in environmental science and Experts $\mathrm{C}, \mathrm{D}$ and $\mathrm{F}$ had a doctor's degree in biology, geography or agriculture) and professional experience in the agricultural industry (Experts B, F and G) or in environmental protection (Experts D and E).

The experts' replies were evaluated with regard to the extent of agreement among the experts. In the case of direct evaluation of parameters, the agreement was identified by means of Kendall's W (Kendall, 1955) according to Equation 1:

$$
W=\frac{12 \sum_{i=1}^{n}\left\{\sum_{j=1}^{m} r_{i j}-\frac{1}{2} m(n+1)\right\}^{2}}{m^{2}\left(n^{3}-n\right)}
$$

where, W - coefficient of concordance

$\mathrm{n}$ - number of factors to be rated

$\mathrm{m}$ - number of experts 
$r_{i j} \quad-i$-th item's rank given by the $j$-th expert

The value of the coefficient of concordance may vary within a range of $0 \leq W \leq 1 ; W=0$ if there is no agreement among experts and $W=1$ if all the experts are unanimous. It is assumed that a sufficient value of the coefficient of concordance is $\mathrm{W} \geq 0.50$, which means that the experts' unanimity is high enough (Kendall, 1955).

The experts evaluated control methods for Sosnowsky's hogweed on a scale from 1 (the highest rank/place) to 5 (the lowest rank/place). The experts' replies are summarised in Table 2.

Table 2

Expert evaluation results

(authors' calculations based on data acquired in April 2016)

\begin{tabular}{|c|c|c|c|c|c|c|c|c|c|c|c|}
\hline & \multicolumn{7}{|c|}{ Experts } & \multirow{3}{*}{ 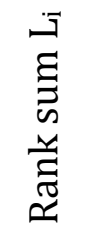 } & \multirow{3}{*}{ 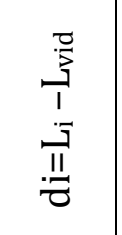 } & \multirow{3}{*}{ di2 } & \multirow{3}{*}{ 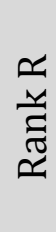 } \\
\hline & A & $\mathrm{B}$ & $\mathrm{C}$ & $\mathrm{D}$ & $\mathrm{E}$ & $\mathrm{F}$ & $\mathrm{G}$ & & & & \\
\hline & \multicolumn{7}{|c|}{ Ranks } & & & & \\
\hline Soil tillage & 3 & 3 & 2 & 3 & 4 & 2 & 2 & 19 & -0.6 & 0.36 & 3 \\
\hline Chemical control & 2 & 2 & 4 & 2 & 3 & 2 & 3 & 18 & -1.6 & 2.56 & 2 \\
\hline Biological control & 4 & 4 & 5 & 2 & 2 & 3 & 4 & 24 & 4.4 & 19.36 & 4 \\
\hline Combined method & 1 & 1 & 1 & 1 & 1 & 1 & 1 & 7 & -12.6 & 158.76 & 1 \\
\hline Other method & 5 & 5 & 3 & 4 & 5 & 3 & 5 & 30 & 10.4 & 108.16 & 5 \\
\hline$n=5$ & \multicolumn{7}{|c|}{$\mathrm{m}=7$} & $\begin{array}{c}\sum \mathrm{L}_{\mathrm{i}}= \\
98\end{array}$ & 0 & $\begin{array}{c}S= \\
289.20\end{array}$ & \\
\hline
\end{tabular}

The calculated coefficient of concordance $\mathrm{W}=0.59$ indicates that in general the experts were quite unanimous and considered the combined method, chemical control and soil tillage to be the most effective methods to control Sosnowsky's hogweed. Justifying the choice of the combined method as the most effective one for the control of Sosnowsky's hogweed, the experts preferred various combinations of soil tillage, chemical control and biological control. The experts stressed the complexity of control methods for Sosnowsky's hogweed and the individual approach to be applied to their combinations depending on the location of a particular territory.

The experts recommended land owners and managers in Rezekne municipality to use soil tillage, chemical control (application of herbicides), biological control (grazing), the combined method as well as other methods (e.g. moving). However, the experts were almost unanimous (5 out of the 7 experts) in recommending land owners and managers in Rezekne municipality to use the combined method, which 
once again confirmed the mentioned method's effectiveness in controlling Sosnowsky's hogweed.

It is important to note that a similar survey was conducted in Poland. According to this survey, $81.8 \%$ of the experts preferred digging up the plant's root and $78.2 \%$ gave preference to disposing its seeds (Olszańka et al., 2016).

The authors' survey focused also on the experts' opinion about public awareness of Sosnowsky's hogweed. As regards the public awareness of this weed in Rezekne municipality, all the experts agreed or partly agreed with an assertion that the public can recognise Sosnowsky's hogweed in nature (Figure 1).

can choose appropriate (effective and efficient) control methods

know how to control the weed

are interested in controlling the weed

are aware of the presence of the weed in their or neighbouring...

are sufficiently informed about its hazards

can recognise it in nature

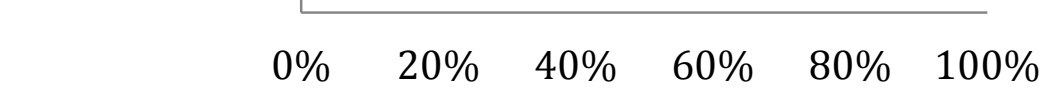
42,86
57,14

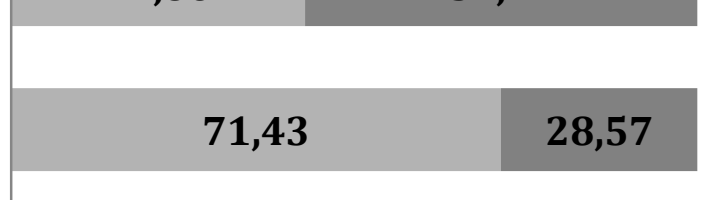

42,86

57,14
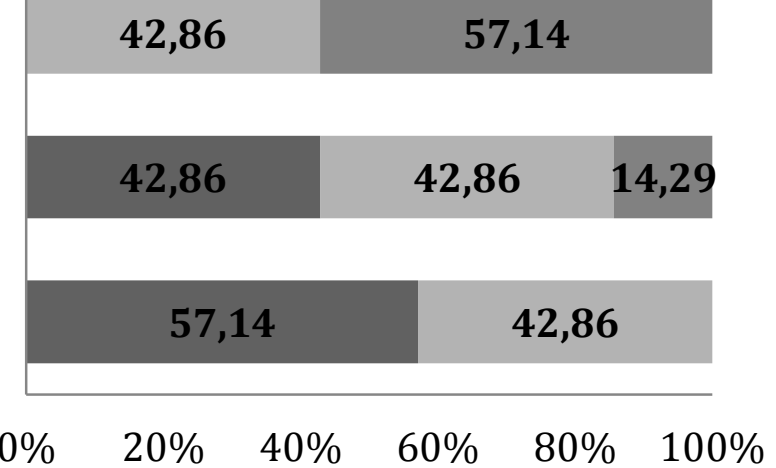

agree $\square$ partly agree $\square$ disagree

Figure 1. Percentage distribution of the experts' replies regarding the public awareness of the presence of Sosnowsky's hogweed in Rezekne municipality in the survey ( $\mathrm{n}=7$ ) (authors' construction)

The experts believed that the public were well informed about the hazards arising from Sosnowsky's hogweed, as 6 out of the 7 experts or $85.72 \%$ agreed or partly agreed with the assertion. Replying to the next assertion regarding whether the public on the whole as well as land owners/managers in particular inform local responsible institutions about the presence of Sosnowsky's hogweed in their or neighbouring territories, the experts' opinions were as follows: partly agree and disagree. This means that the experts believed that land owners/managers often did not 
inform their local responsible institutions about the presence of Sosnowsky's hogweed in their or neighbouring territories. The experts agreed or partly agreed to an assertion that the public on the whole as well as land owners and managers are interested in controlling Sosnowsky's hogweed.

As regards the skill of land owners and managers to control Sosnowsky's hogweed, the experts only partly agreed $(71.43 \%)$ and disagreed $(28.57 \%)$ with an assertion that land owners and managers know how to control Sosnowsky's hogweed. The experts only partly agreed (42.86\%) and disagreed (57.14\%) that land owners and managers could choose appropriate (effective and efficient) control methods for Sosnowsky's hogweed.

After analysing the experts' replies regarding the public awareness of the presence of Sosnowsky's hogweed in Rezekne municipality, one can conclude that the public on the whole as well as land owners and managers:

- can recognise Sosnowsky's hogweed in nature and are sufficiently informed about hazards arising from it and are interested in controlling this weed;

- $\quad$ often do not inform their local responsible institutions about the presence of Sosnowsky's hogweed in their or neighbouring territories;

- however, do not know how to control Sosnowsky's hogweed and are not able to choose correct (effective and efficient) control methods.

In the experts' opinion on the ways of informing the public about the control of Sosnowsky's hogweed and the hazards that are caused by this plant in Rezekne municipality, the most effective ways are as follows:

- meeting professionals in person (meetings, seminars, experience exchange activities etc.);

- $\quad$ articles in newspapers and magazines;

- $\quad$ other (e.g. billboards next to hogweed stands along roadsides, where people can acquire basic information, Latvian Rural Advisory and Training Centre specialists disseminate information or give oral advice) (Figure 2). 


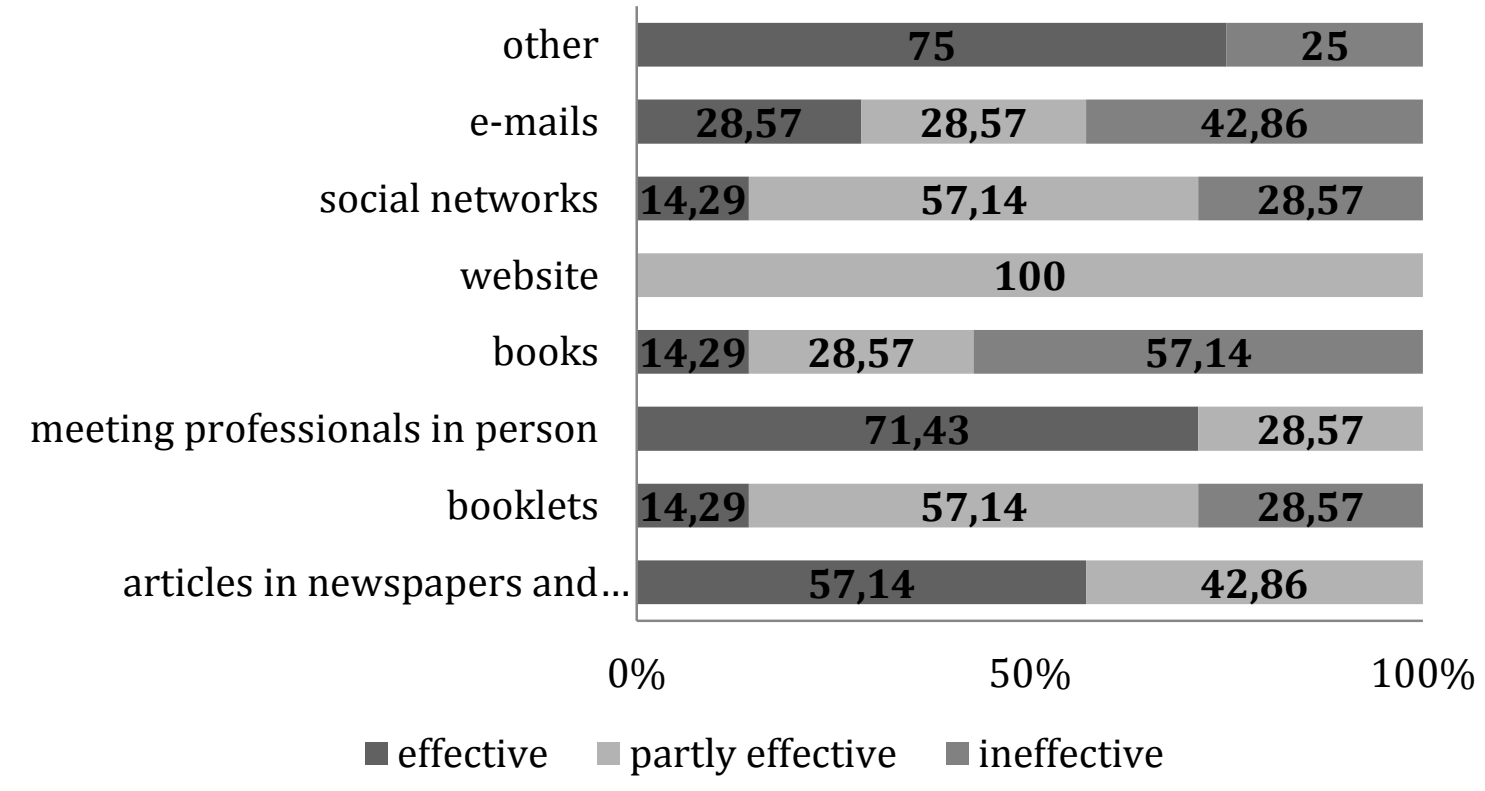

Figure 2. Percentage distribution of the experts' replies regarding the most effective ways of informing the public about the control of Sosnowsky's hogweed and the hazards arising from it in Rezekne municipality in the survey ( $\mathrm{n}=7$ ) (authors' construction)

In Rezekne municipality, in the experts' opinion, a special website on the management of agricultural land, booklets and social networks (facebook.com, twitter.com, draugiem.lv etc.) are the most effective ways to inform the public about the control of Sosnowsky's hogweed and the hazards arising from this plant. Books, which give advice and abundant information, as well as e-mails are the most ineffective ways for informing the public about the mentioned matters, according to the experts.

\section{Conclusions and suggestions}

1. Local species are endangered with the spread of Sosnowsky's hogweed. In Rezekne municipality, in 16 out of its 25 rural territories Sosnowsky's hogweed was present in an area of 84.39 ha.

2. The largest areas with Sosnowsky's hogweed in Rezekne municipality were identified in Berzgale rural territory, 57.38 ha or $66.42 \%$ of the municipality's total area with this weed, as well as in the rural territories of Silmala (7.99 ha) and Nagli (7.3 ha).

3. The experts recommended land owners and managers in Rezekne municipality to use soil tillage, chemical control (application of herbicides), biological control (grazing), the combined method as well as other methods (e.g. moving). However, the experts 
unanimously regarded the combined method as the most effective one.

4. The experts believed that land owners and managers in Rezekne municipality did not choose the most effective and efficient methods to control Sosnowsky's hogweed.

5. The State Plant Protection Service in cooperation with the national institutions supervised by the Ministry of Environmental Protection and Regional Development should use the most effective (in the experts' opinion) way of informing the public about control methods for Sosnowsky's hogweed, holding in-person meetings and seminars with professionals for land owners and users.

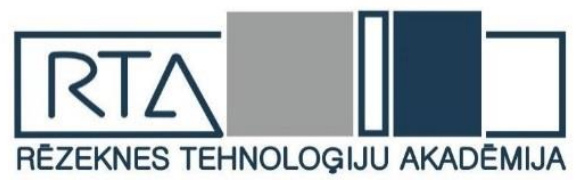

The research was elaborated with the financial assistance of Rezekne Academy of Technologies provided through a research grant for the "Investigation into the Information Society regarding the Control and Hazards of Sosnowsky's Hogweed in Rezekne Municipality".

\section{References}

1. BĒRZIN̦Š, A., LAPIN̦Š, D., LEJIN̦Š, A., KUKLE, I., GAVRILOVA, G.., PRIEKULE, I., VANAGA, I., TREIKALE, O., LIGUTS, V., OLUUKALNS, A., RIEKSTIN,Š, A., KARPENSKIS, G. 2007. Latvānis, tā izplatības ierobežošana. Informatīvs materiāls. LR Vides ministrija, LR Zemkopības ministrija, LLU, Valsts SIA „Augus aizsardzības pētniecības centrs”, Valsts SIA „Vides projekti”, LVAF. 55 lpp.

2. Bioloğiskās daudzveidības konvencija (1996) Retrieved May 15, 2016, from http://likumi.lv/doc.php?id=207856

3. Bioloğiskās daudzveidības nacionālā programma (2003) Retrieved May 10, 2016, from http://www.varam.gov.lv/lat/publ/politikas_planosanas dokumenti/?doc $=5388$

4. LAIVIN̦Š, M., GAVRILOVA, G̣. 2003. Neofitās Sosnovska latvāṇa Heracleum sosnowskyi sabiedrības Latvijā. Latvijas veǵetācija: 7: 45-65.

5. KENDALL, M., G. (1955) Rank Correlation Methods. New York, Hafner Publishing Co.

6. OLSZAŃKA, A., SOLARZ, W., NAJBEREK, K. (2016) To killornot to kill Practitioners' opinions on invasive alien species management as a step towards enhancing control of biological invasions. - Environmental Science \& Policy 58 107-116.

7. PRIEDE, A. (2008) Invazīvo svešzemju augu sugu izplatība Latvijā. - Latvijas veǵetācija 17, Rīga, 148 lpp.

8. Rēzeknes novada pašvaldības sniegtā informācija, 2016.

9. TRIPĀNE, E. (2013) Sosnovska latvāṇa izplatība un tā ietekmējošie faktori Rāznas nacionālā parka teritorijā. 17. starptautiskajā studentu zinātniski - 
praktiskajā konferences CILVĒKS. VIDE. TEHNOLOG̣IJAS. rakstu krājums, 253260 lpp.

10. VILCĀNE, V. (2013) Latvānis privātā zemē. Kas jāzina zemes īpašniekiem un valdītājiem Retrieved May 14, 2016, from http://m.lvportals.lv/ visi/skaidrojumi/257315-latvanis-privata-zeme-kas-jazina-zemesipasniekiem-un-valditajiem/ 


\title{
SOSNOVSKA LATVĀṆA HERACLEUM SOSNOWSKYI APKAROŠANAS METOŽU IZVĒRTĒJUMS RĒZEKNES NOVADĀ: EKSPERTU APTAUJAS REZULTĀTI
}

\author{
Anda ZVAIGZNE1 ${ }^{\text {, Inta KOTĀNE }}{ }^{2}$, Anna MEŽAKA ${ }^{3}$ \\ ${ }^{1}$ Dr.oec., Rēzeknes Tehnoloǵiju akadēmija, vadošā pētniece un asociētā profesore \\ ${ }^{2}$ Mg.oec., Rēzeknes Tehnologiju akadēmija, pētniece un lektore \\ 3 Dr.biol., Rēzeknes Tehnologiju akadēmija, vadošā pētniece un viesdocente
}

\section{Kopsavilkums}

Pētījums tika veikts, risinot ne tikai aktuālu problēmu Rēzeknes novadā, bet visā pasaulē kopumā. Arvien vairāk zinātnieku un pētnieku vidū rodas diskusijas par svešo sugu naturalizācijas un izplatību, kas izspiež vietējās sugas. Viena no šādām sugām ir Sosnovska latvānis, kas rada problēmas zemju īpašniekiem/apsaimniekotājiem, kā arī vietējiem iedzīvotājiem Rēzeknes novadā.

Raksta mērḳis ir izvērtēt ekspertu viedokli par Sosnovska latvānna apkarošanas metožu pielietojumu Rēzeknes novadā. Pētījuma mērksa sasniegšanai izvirzītie uzdevumi: 1) raksturot Sosnovska latvān, izplatības situāciju Rēzeknes novadā; 2) pielietojot ekspertu metodi, noskaidrot efektīvākās Sosnovska latvān,a apkarošanas metodes un to pielietojumu Rēzeknes novadā.

Pielietotās pētījuma metodes: monogrāfiski aprakstošā metode, analīze, sintēzes, datu grupēšanas un sociologiskā pētījuma metode - ekspertu aptauja. Ekspertu aptaujas datu vienprātības analīzē pielietots Kendela konkordācijas (W) koeficients.

Pētijjuma rezultāti parāda, ka eksperti kopumā bijuši vienoti savos uzskatos (W=0.59) un vienprātīgi atzinuši par Sosnovska latvāṇa apkarošanas efektīvākajām metodēm kombinēto metodi, k̦īmisko metodi (herbicīdu izmantošana) un augsnes apstrādes metodi. Kā arī eksperti uzskata, ka zemju īpašnieki un apsaimniekotāji Rēzeknes novadā neizvēlās efektīvākās un lētākās Sosnovska latvāṇa apkarošanas metodes.

Darbs izstrādāts ar Rēzeknes Tehnoloǵiju akadēmijas zinātniskā granta pētniecībai finansiālu atbalstu.

Atslēgas vārdi: Sosnovska latvānis; zemju īpašnieki un apsaimniekotāji; efektīvākās metodes; ekspertu viedoklis; Rēzeknes novads. 